Iwona Kopacz-Wyrwal

Uniwersytet Jana Kochanowskiego

w Kielcach

\title{
Przedsiębiorczość a poziom życia na obszarach wiejskich Polski Wschodniej
}

\section{Entrepreneurship vs the standard of living in the rural areas of Eastern Poland}

\begin{abstract}
Streszczenie
Celem niniejszej pracy jest analiza przestrzennego zróżnicowania poziomu przedsiębiorczości oraz poziomu życia ludności na obszarach wiejskich Polski Wschodniej. Ponadto podjęto próbę określenia zależności między poziomem życia ludności wiejskiej a przedsiębiorczością. Badaniem objęto wszystkie gminy wiejskie oraz część wiejską w gminach miejsko-wiejskich z obszarów pięciu województw, tj. świętokrzyskiego, podkarpackiego, lubelskiego, podlaskiego i warmińsko-mazurskiego. W sumie analizie poddano 639 gmin. Poziom życia wyrażono syntetycznym wskaźnikiem Perkala, natomiast do przedstawienia poziomu przedsiębiorczości wykorzystano wskaźnik przedsiębiorczości. Przeprowadzona analiza wykazała, że zarówno obecny poziom przedsiębiorczości, jak i poziom życia na obszarach wiejskich Polski Wschodniej są wypadkową oddziaływania wielu czynników i wykazują duże przestrzenne zróżnicowanie, co wynika z ogólnego rozwoju społeczno-ekonomicznego tych obszarów. Ponadto przeprowadzone badania wykazały, że wysokim poziomem życia ludności oraz wysokim poziomem przedsiębiorczości charakteryzują się jednostki przestrzenne zlokalizowane w sąsiedztwie największych ośrodków miejskich, położone wzdłuż głównych szlaków komunikacyjnych oraz te o dobrze rozwiniętych funkcjach turystycznych.
\end{abstract}

\begin{abstract}
The aim of this study is the analysis of the spatial diversification of the level of entrepreneurship and the standard of living in rural areas in Eastern Poland. Moreover, the author attempts to determine the relationships between the standard of living and entrepreneurships. Research included all the rural communes [Translator's note: communes - Polish gmina - the principal unit of territorial and administrative division in Poland] and the rural parts of urban-rural communes located in the area of five voivodeships, namely Swietokrzyskie, Podkarpackie, Lubelskie, Podlaskie and Warminsko-Mazurskie Voivodeships, i.e. 639 communes. The standard of living has been expressed by Perkal's index, whereas an entrepreneurship indicator was employed to present the level of entrepreneurship. The analysis conducted revealed that the present level of entrepreneurship and living conditions in the rural areas of Eastern Poland are a result of the influence of many factors and show high spatial diversity, which results from the general social and economic development of these areas. Moreover, the research conducted showed that high living standards and high levels of entrepreneurship characterise spatial units located in the neighbourhood of the largest urban centres, along main routes, and those with well-developed tourist functions.
\end{abstract}

Słowa kluczowe: obszary wiejskie; Polska Wschodnia; poziom życia; przedsiębiorczość Keywords: rural areas; entrepreneurship; Eastern Poland; standard of living 


\section{Wstęp}

Zachodzące w ciągu ostatnich dekad przemiany na obszarach wiejskich ukształtowały współczesny, bardzo zróżnicowany obraz warunków życia i poziomu gospodarczego tych terenów w poszczególnych krajach Europy, regionach i gminach. Dlatego też zagadnienia rozwoju społeczno-gospodarczego stanowią obecnie kluczowy przedmiot rozważań teoretycznych i praktycznych w krajach Unii Europejskiej. Problematyka ta jest niezmiernie istotna, ponieważ w dobie globalizacji i integracji nadmierne różnice w poziomie rozwoju poszczególnych regionów stanowią barierę w funkcjonowaniu wspólnego rynku, a tym samym hamują rozwój przedsiębiorczości. Przedsiębiorczość z kolei jest podstawą i warunkiem innowacyjnego rozwoju gospodarki, podnoszenia poziomu życia społeczeństwa oraz indywidualnej zamożności. Zapewnia również stałe zwiększanie i doskonalenie podaży towarów oraz usług, a także wzrost zatrudnienia, potencjału i konkurencyjności krajowej gospodarki na rynkach światowych (Sztucki, 1998). W związku z tym najważniejszym celem krajowej i europejskiej polityki regionalnej staje się obecnie dążenie do zmniejszania przestrzennych zróżnicowań w poziomie rozwoju społeczno-gospodarczego poszczególnych regionów (Kudełko, 2013).

Działania te są szczególnie istotne dla obszarów wiejskich położonych w regionach peryferyjnych, do których zaliczana jest Polska Wschodnia - traktowana jako europejski obszar problemowy (Miszczuk, Wesołowska, 2012). Region Polski Wschodniej należy do najsłabiej rozwiniętych obszarów Unii Europejskiej i obejmuje pięć województw o najniższym poziomie PKB per capita, tj. świętokrzyskie, podkarpackie, lubelskie, podlaskie i warmińsko-mazurskie.

W świetle powyższych uwag celem niniejszego opracowania jest określenie zależności między poziomem przedsiębiorczości a poziomem życia ludności wiejskiej Polski Wschodniej. Dlatego też niniejsza praca badawcza obejmowała trzy etapy:

1) analizę przestrzennego zróżnicowania poziomu przedsiębiorczości na obszarach wiejskich Polski Wschodniej,

2) analizę przestrzennego zróżnicowania poziomu życia ludności na obszarach wiejskich Polski Wschodniej,

3) określenie zależności (korelacji) między badanymi cechami.

Na podstawie dotychczasowych badań prowadzonych w różnych regionach kraju (Bański, 2008; Baran, Kopacz-Wyrwał, 2014; Gaweł, 2007; Heffner, 2007; Jaremczuk, 2003; Kamińska, 2010; Makieła, 2008; Stanny, 2009; Zeliaś, 2004 i inni) wstępnie sformułowano następujące hipotezy badawcze:

- na obszarach wiejskich Polski Wschodniej występuje znaczne zróżnicowanie przestrzenne poziomu przedsiębiorczości i poziomu życia ludności,

- wysoki poziom życia i wysoki poziom przedsiębiorczości występuje w gminach położonych w sąsiedztwie dużych ośrodków miejskich, wzdłuż głównych szlaków komunikacyjnych oraz na obszarach o dobrze wykształconych funkcjach usługowych, przemysłowych i mieszkaniowych,

- niski poziom życia i niski poziom przedsiębiorczości cechuje obszary peryferyjne, monofunkcyjne rolniczo, borykające się z niekorzystnymi procesami demograficznymi i społecznymi,

- istnieje silna korelacja między przedsiębiorczością a poziomem życia ludności wiejskiej, a największa cechuje obszary sukcesu gospodarczego.

Przedsiębiorczość można definiować, biorąc pod uwagę różne aspekty, ponieważ jest ona wielowątkowym tematem badawczym. Każde z ujęć inaczej definiuje, analizuje i interpretuje fenomen przedsiębiorczości (Wach, 2013). Jak podaje A. Gaweł (2007: 13), „ekonomiści 
zajmujący się badaniem przedsiębiorczości uważają, że brakuje kompleksowej i jednolitej teorii przedsiębiorczości czy nawet jej definicji, co jest wynikiem wielowątkowości zagadnień poruszanych przy jej badaniu oraz interdyscyplinarnego charakteru tego fenomenu".

Za twórcę teorii przedsiębiorczości uznaje się Schumpetera (1960), który definiował ją jako proces twórczej destrukcji, w której wyniku powstają nowe kombinacje w sferze wytwarzania, będące zalążkiem działań przedsiębiorczych. Współcześnie pojęcie to jest przede wszystkim rozumiane jako specyficzny rodzaj aktywności człowieka, wrodzona cecha osobowości, która wyraża się w jego twórczym działaniu, zmierzającym do zapewnienia racjonalnej i efektywnej koordynacji zasobów gospodarczych oraz umożliwiająca osiąganie racjonalności gospodarowania i efektywności ekonomicznej (Makieła, 2008). Jaremczuk (2003) definiuje przedsiębiorczość jako określoną siłę społeczno-ekonomiczną, mającą nie tylko wymiar ekonomiczny, lecz także osobowy, społeczny i kulturowy.

Zdaniem Kaliszczak (2002) przedsiębiorczość oznacza proces identyfikacji i wykorzystania szans, niezależnie od aktualnych zasobów materialnych. Z kolei według Targalskiego (1999: 17) przedsiębiorczość to „zdolność do tego, żeby być przedsiębiorczym, posiadanie ducha inicjatywy, obrotność, rzutkość, zaradność”. Autor ten stwierdza również, że ,zgodnie z nowoczesnymi koncepcjami przedsiębiorczość traktowana jest jako proces inicjowania i wprowadzania zmian, zanikający okresowo do czasu pojawienia się nowych inicjatyw. Jest to proces tworzenia czegoś nowego i wartościowego, z założeniem osobistego ryzyka finansowego, ale także z założeniem rekompensaty pieniężnej lub osobistej satysfakcji”. Natomiast Leszczewska (2012) podaje, że przedsiębiorczość w ujęciu regionalnym jest silnie zróżnicowana, ponieważ regiony różnią się strukturą gospodarczą, dostępnością infrastruktury technicznej, poziomem rozwoju instytucji otoczenia biznesu, aktywnością samorządów oraz jakością kapitału ludzkiego.

W niniejszej pracy termin przedsiębiorczość rozumiany jest jako cecha osobowości człowieka, wyrażająca się w jego twórczym działaniu polegającym na tworzeniu i rozwoju prywatnej działalności gospodarczej, podejmowanej na własne ryzyko. Natomiast poziom życia autorka rozumie jako stopień zaspokojenia potrzeb materialnych, kulturalnych i duchowych społeczeństwa przez strumień dóbr i usług odpłatnych. Takie podejście prezentowali w swoich pracach m.in.: Luszniewicz (1983), Bywalec (1986), Liszewski (1995), Szymla (2004).

Badaniem objęto wszystkie gminy wiejskie oraz część wiejską w gminach miejsko-wiejskich z obszaru pięciu województw, tj. świętokrzyskiego, podkarpackiego, lubelskiego, podlaskiego i warmińsko-mazurskiego. W sumie analizie poddano 639 gmin, na terenie których zamieszkiwało 4177,4 tys. osób, co stanowiło 27,5\% ogólnej liczby ludności wiejskiej kraju.

\section{Metody badań}

Do ustalenia poziomu przedsiębiorczości wykorzystano w pracy wskaźnik przedsiębiorczości, który jest jednym z podstawowych wskaźników określających aktywność gospodarczą ludności danego obszaru, obrazującym liczbę podmiotów gospodarczych danej jednostki terytorialnej na 1 tys. osób w wieku produkcyjnym. Natomiast poziom życia wyrażono syntetycznym wskaźnikiem skonstruowanym metodą sum standaryzowanych (wskaźnik Perkala), z wykorzystaniem 14 cech cząstkowych (tab. 1). Metoda sum standaryzowanych w polskich badaniach geograficzno-ekonomicznych ma wieloletnią tradycję i daje dobre rezultaty. W swych pracach stosowali ją m.in.: Chojnicki, Czyż (1991), Zeliaś (2000), Rosner (2007) oraz Kamińska (2010). 
Tab. 1. Mierniki poziomu życia zastosowane w pracy

\begin{tabular}{|c|c|c|}
\hline Mierniki & & Wyszczególnienie (2012 r.) \\
\hline \multirow{6}{*}{ 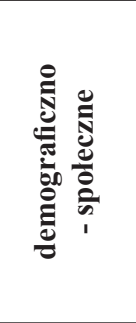 } & 1 & Zgony ogółem na 1 tys. mieszkańców \\
\hline & 2 & Liczba osób na 1 aptekę \\
\hline & 3 & Liczba osób na 1 placówkę biblioteczną \\
\hline & 4 & $\begin{array}{l}\text { Uczniowie przypadający na } 1 \text { komputer z dostępem do internetu przeznaczony } \\
\text { do użytku uczniów (szkoły podstawowe }+ \text { gimnazja) }\end{array}$ \\
\hline & 5 & Współczynnik skolaryzacji netto (gimnazja) \\
\hline & 6 & $\begin{array}{l}\text { Liczba osób w gospodarstwach domowych korzystająca ze środowiskowej } \\
\text { pomocy społecznej w stosunku do ludności ogółem }\end{array}$ \\
\hline \multirow{6}{*}{ 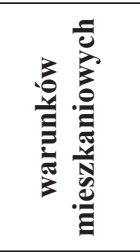 } & 7 & Powierzchnia użytkowa mieszkań na 1 osobę w m² \\
\hline & 8 & Mieszkania wyposażone w łazienki w \% ogółu mieszkań \\
\hline & 9 & Ludność korzystająca z oczyszczalni w \% ogółu ludności \\
\hline & 10 & Ludność korzystająca z instalacji wodociągowej w \% ogółu ludności \\
\hline & 11 & Sieć rozdzielcza kanalizacyjna na $100 \mathrm{~km}^{2}$ \\
\hline & 12 & Sieć rozdzielcza gazowa na $100 \mathrm{~km}^{2}$ \\
\hline \multirow{2}{*}{ 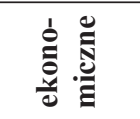 } & 13 & Wydatki budżetów jednostek samorządu terytorialnego na 1 mieszkańca \\
\hline & 14 & $\begin{array}{l}\text { Udział bezrobotnych zarejestrowanych w liczbie ludności w wieku produkcyjnym } \\
\text { w } \%\end{array}$ \\
\hline
\end{tabular}

Źródło: opracowanie własne na podstawie www.stat.gov.pl.

Przy doborze mierników określających poziom życia ludności wiejskiej Polski Wschodniej zwracano szczególną uwagę, aby wybrane cechy możliwie wszechstronnie charakteryzowały poziom życia ludności badanych jednostek oraz odznaczały się relatywnie dużym zróżnicowaniem przestrzennym. Ponadto powinny się one opierać na ogólnie dostępnych informacjach statystycznych, porównywalnych zarówno w czasie, jak i przestrzeni.

Początkowo wybrano 27 mierników, jednak wstępna obróbka statystyczna - m.in. analiza współczynników korelacji i zmienności - pozwoliła na zredukowanie tej liczby do 14. Wartości współczynnika zmienności wyrażone w procentach dla dobranych cech wahają się od 25,1 do 130,7 przy średniej 55,9. Natomiast współczynniki korelacji między poszczególnymi miernikami zawierają się w przedziale od $-0,53$ do 0,49 , co pozwala przyjąć je do dalszej analizy oraz uznać, że dobrane cechy mają zarówno odpowiednią zmienność przestrzenną, jak i istotną wartość informacyjną. Standaryzowane wartości mierników cząstkowych, mających charakter destymulant (mierniki 1, 2, 3, 4, 6 i 14), pomnożono przez (-1) w celu uzyskania dla każdej jednostki przestrzennej 14 jednakowo ukierunkowanych wartości standaryzowanych.

Mierniki podzielono na demograficzno-społeczne, mierniki warunków mieszkaniowych oraz ekonomiczne. Pierwsza grupa, tj. mierniki demograficzno-społeczne, pozwala na ocenę zróżnicowania stanu zdrowia ludności (stopa zgonów), dostępności do usług socjalnych i kulturalnych (liczba osób na 1 aptekę oraz liczba osób na 1 placówkę biblioteczną), poziomu kształcenia i jego powszechności (uczniowie przypadający na 1 komputer $\mathrm{z}$ dostępem do internetu, współczynnik skolaryzacji netto), a także stanu zamożności społeczeństwa (liczba osób w gospodarstwach domowych korzystająca ze środowiskowej pomocy społecznej).

Grupa druga: mierniki warunków mieszkaniowych informuje o stanie i dynamice budownictwa (powierzchnia użytkowa mieszkań na 1 osobę), standardzie mieszkań (mieszkania wyposażone w łazienki w \% ogółu mieszkań) oraz o stanie infrastruktury technicznej (ludność korzystająca z oczyszczalni i instalacji wodociągowej w \% ogółu ludności, sieć rozdzielcza 
kanalizacyjna i gazowa na $100 \mathrm{~km}^{2}$ ). Jak zauważa Hydzik (2012: 24), „stan infrastruktury społecznej i technicznej jest istotnym uwarunkowaniem współczesnego rozwoju społeczno-ekonomicznego", a tym samym przesłanką decydującą o poziomie życia ludności. Z całą stanowczością należy stwierdzić, że braki infrastrukturalne są barierą rozwojową, zwłaszcza dla obszarów wiejskich.

Mierniki ekonomiczne ukazują z kolei wiele interesujących zjawisk na rynku gospodarczym i rynku pracy. Informują przede wszystkim o aktywności inwestycyjnej oraz zamożności jednostek przestrzennych (wydatki budżetów jednostek samorządu terytorialnego na 1 mieszkańca), a także aktywności gospodarczej społeczeństwa (udział bezrobotnych zarejestrowanych w liczbie ludności w wieku produkcyjnym). Należy podkreślić, że inwestycje publiczne są ważnym warunkiem rozwoju gospodarczego, a tym samym poprawy poziomu życia ludności (Swianiewicz, 2005).

Powyższe mierniki są powszechnie stosowane w badaniach poziomu życia ludności. W swych pracach stosowali je m.in.: Luszniewicz (1972), Piasny (1993), Berbeka (2006), Szymla (2004), Zeliaś (2000, 2004), Słaby (2007), Zagórski, Gorzelak, Jałowiecki (2009), Kopacz (2011) i wielu innych. Należy zdawać sobie jednak sprawę z tego, że o poziomie życia ludności decyduje wiele różnych czynników i niemożliwe jest uwzględnienie w danym badaniu wszystkich zmiennych jednocześnie. Ponadto część z nich jest trudna, a czasem wręcz niemożliwa do zbadania, dlatego też w analizie poziomu życia zazwyczaj ujmuje się takie zmienne i dane, które są ogólnie dostępne oraz porównywalne zarówno w czasie, jak i przestrzeni.

W niniejszej pracy przy doborze mierników wykorzystano dane liczbowe dostępne w Banku Danych Lokalnych GUS dla modułu gminnego za 2012 r. Autorka uważa, że istniejące materiały statystyczne pozwalają określić poziom życia ludności, a przynajmniej uzyskać obraz zróżnicowania stopnia zaspokojenia niektórych potrzeb ogólnospołecznych na obszarach wiejskich Polski Wschodniej (Kopacz, 2011).

\section{Przedsiębiorczość na obszarach wiejskich Polski Wschodniej}

W 2012 r. na obszarach wiejskich Polski Wschodniej zaobserwowano znaczne zróżnicowanie przestrzenne poziomu przedsiębiorczości (ryc. 1). Wskaźnik przedsiębiorczości wahał się tam w przedziale od 26 w gminie Korsze (województwo warmińsko-mazurskie) do 201 w gminie Lutowiska (województwo podkarpackie), przy średniej wartości 64,6 (tab. 2, ryc. 1). Dla porównania na obszarach wiejskich Polski wskaźnik ten był wyższy i wyniósł 88. Przyjmując za kryterium wartości powyższego wskaźnika, na obszarach wiejskich Polski Wschodniej wyróżniono pięć klas gmin: o bardzo niskim, niskim, średnim, wysokim oraz bardzo wysokim poziomie przedsiębiorczości.

Tab. 2. Poziom przedsiębiorczości na obszarach wiejskich Polski Wschodniej w 2012 r.

\begin{tabular}{|l|r|r|r|c|}
\hline \multirow{2}{*}{ Wskaźnik przedsiębiorczości } & \multicolumn{2}{c|}{ Liczba } & \multicolumn{2}{c|}{ Struktura [\%] } \\
\cline { 2 - 5 } & gmin & \multicolumn{1}{c|}{ ludności } & gmin & ludności \\
\hline Bardzo niski (46,1 i mniej) & 86 & 393521 & 13,5 & 9,4 \\
\hline Niski $(46,2-64,5)$ & 281 & 1626495 & 44,0 & 38,9 \\
\hline Średni $(64,6-82,9)$ & 175 & 1293798 & 27,4 & 31,0 \\
\hline Wysoki (83,0-101,3) & 66 & 599444 & 10,3 & 14,4 \\
\hline Bardzo wysoki (101,4 i więcej) & 31 & 264117 & 4,8 & 6,3 \\
\hline Razem & 639 & 4177375 & 100,0 & 100,0 \\
\hline
\end{tabular}

Źródło: opracowanie własne na podstawie www.stat.gov.pl. 
Ryc. 1. Przestrzenne zróżnicowanie wskaźnika przedsiębiorczości na obszarach wiejskich Polski Wschodniej

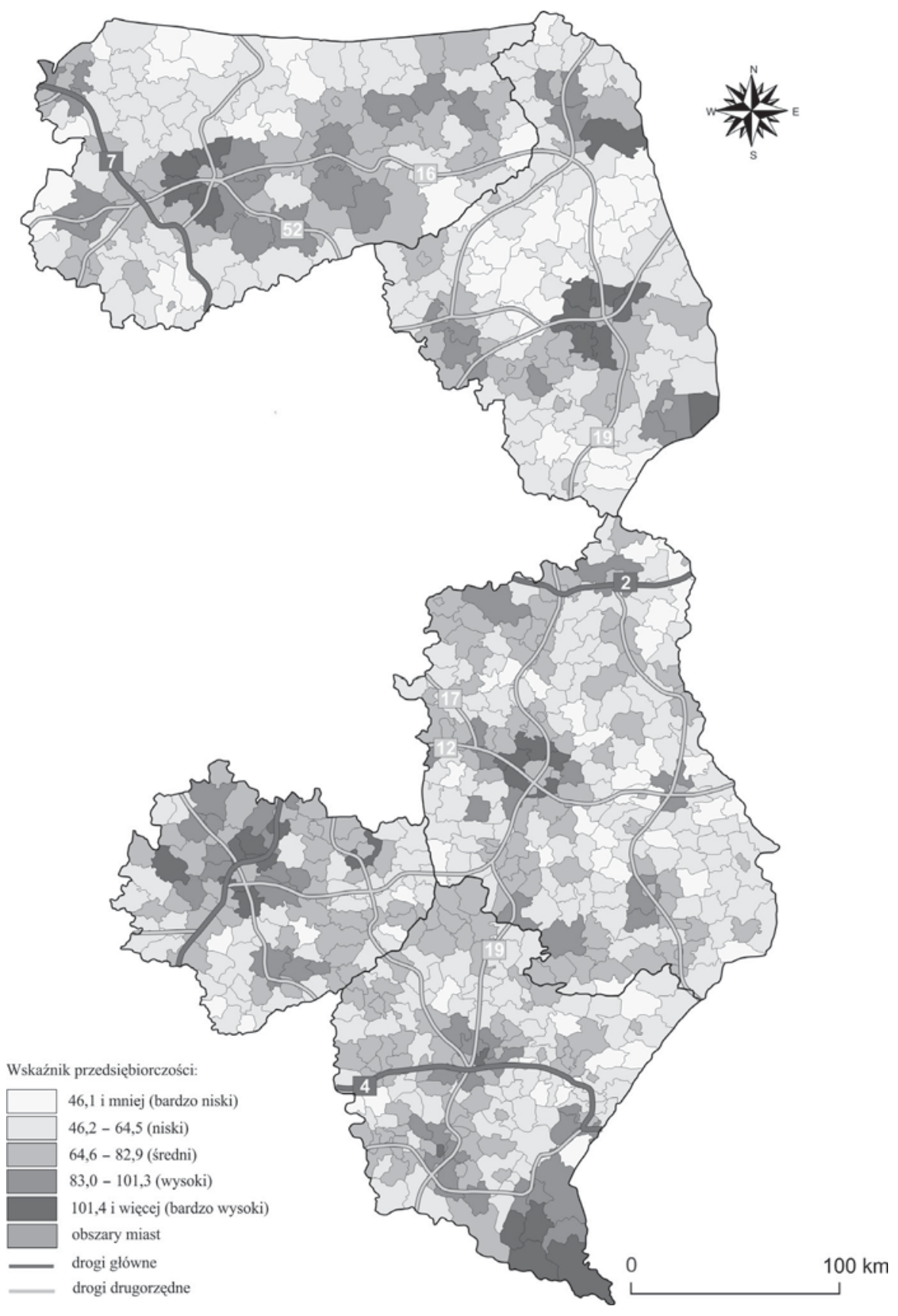

Źródło: opracowanie własne na podstawie www.stat.gov.pl. 
Gminy o bardzo niskim poziomie przedsiębiorczości charakteryzowały jednostki, gdzie wskaźnik przyjął wartości poniżej 46,1. W grupie tej znalazło się 86 gmin (13,5\% ogółu), które skupiły 9,4\% ludności wiejskiej regionu. Najniższe wartości odnotowano w gminach Korsze (26, warmińsko-mazurskie), Pruchnik (26, podkarpackie) oraz Nowy Dwór (28, podlaskie). Były to gminy zlokalizowane głównie na obszarach peryferyjnych województw, z dala od dużych ośrodków miejskich, mające charakter rolniczy - przy czym rolnictwo, prowadzone przeważnie w rozdrobnionych, rodzimych gospodarstwach, wykazywało niską towarowość oraz niski poziom kultury rolnej (Kulikowski, 2012). Dodatkowo gospodarstwa te w dużej części należą do emerytów i rencistów (w województwie podkarpackim aż 1/3), co - m.in. przy niskim poziomie wykształcenia ludności rolniczej - wpływa na bardzo wolne tempo procesów modernizacyjnych bądź ich brak. Nawet na obszarach o lepiej rozwiniętym poziomie gospodarki rolnej, np. w pasie ciągnącym się od Łańcuta po Przemyśl, osiągane plony nie odzwierciedlają w pełni jakości przestrzeni produkcyjnej (Bański, 2002). W gminach tych należałoby jak najszybciej podjąć działania zmierzające do podnoszenia kwalifikacji i aktywizacji lokalnych społeczności.

Druga grupa gmin, o niskim poziomie przedsiębiorczości, charakteryzowała jednostki, w których analizowany wskaźnik był niższy niż średnia dla obszarów wiejskich $(46,2-64,5)$. Była to najliczniejsza grupa: 281 gmin (44,0\%), skupiająca 38,9\% ludności wiejskiej regionu. Również i te jednostki wykazywały położenie peryferyjne oraz bezpośrednio sąsiadowały z tymi o bardzo niskim poziomie przedsiębiorczości. Jak wskazują badania (Kamińska, 2011), obszary te cechuje niski poziom wykształcenia ludności wiejskiej, a ludność słabiej wykształcona rzadziej podejmuje ryzyko prowadzenia prywatnej działalności gospodarczej. Jest także niechętna do wprowadzania wszelkich nowości technologicznych w gospodarstwie rolnym z obawy przed niepowodzeniem. Z kolei brak rozwoju prywatnej inicjatywy gospodarczej prowadzi do bardzo małych przychodów gminy, co przyczynia się do słabego inwestowania gminy w infrastrukturę społeczną i techniczną, która mogłaby zachęcić inwestorów.

W kolejnej grupie gmin, o średnim poziomie przedsiębiorczości, analizowany wskaźnik wahał się w granicach 64,6-82,9, czyli już powyżej średniej dla obszarów wiejskich badanego obszaru. Było 175 (27,4\%) takich jednostek przestrzennych, które zamieszkiwało 31,0\% ludności wiejskiej. Leżą one pomiędzy tymi o wysokim i niskim wskaźniku przedsiębiorczości, a dużą ich grupę stanowią części wiejskie gmin miejsko-wiejskich. Cechowały się one towarowym rolnictwem, średnio rozwiniętymi funkcjami pozarolniczymi, a także średnimi zasobami kapitału ludzkiego (Kamińska, 2011).

Grupa gmin o wysokim poziomie przedsiębiorczości - w których analizowany wskaźnik oscylował w przedziale 83,0-101,3 - skupiała 66 jednostek przestrzennych $(10,3 \%)$, na terenie których mieszkało 14,4\% ludności wiejskiej. Położone są one wzdłuż głównych szlaków komunikacyjnych, wokół największych miast regionu (Rzeszów, Kielce, Olsztyn) oraz wokół miast powiatowych (Krosno, Skarżysko-Kamienna, Suwałki, Giżycko, Zamość). W Krośnie, prócz wielu zakładów przemysłu motoryzacyjnego (Opel, Chevrolet, Volkswagen, Skoda, Renault ), działa Huta Szkła „Krosno” SA - będąca do niedawna jednym z liderów rynku światowego w branży szkła gospodarczego. W Skarżysku-Kamiennej natomiast działają Zakłady Zbrojeniowe MESKO S.A., będące częścią Narodowego Koncernu Polski Holding Obronny, oraz funkcjonuje Skarżyska Strefa Gospodarcza. Dlatego też gminy położone w sąsiedztwie wyżej wymienionych miast cechują się wysokimi wskaźnikami poziomu przedsiębiorczości, m.in. dzięki korzyściom z sąsiedztwa rynków miejskich. Ponadto jednostki te mają dobrze rozwinięte funkcje turystyczne (Bański, Stola, 2002). Należą tu m.in. gminy z obszaru Gór Świętokrzyskich, Ponidzia, Bieszczad, Puszczy Białowiejskiej oraz Pojezierza Mazurskiego. 
Ostania klasa to gminy o bardzo wysokim poziomie przedsiębiorczości, gdzie analizowany wskaźnik wyniósł powyżej 101,4. Zaliczono do nich jedynie 31 (4,8\%) jednostek przestrzennych, które skupiały 6,3\% ludności wiejskiej. Najwyższe wartości odnotowano w gminach: Lutowiska (201, podkarpackie), Cisna (185, podkarpackie) i Stawiguda (164, warmińsko-mazurskie). W grupie tej dominowały gminy stref podmiejskich największych miast (Kielce, Lublin, Białystok, Olsztyn), charakteryzujące się dużym odsetkiem ludności w wieku produkcyjnym, w których mieszka ludność dobrze wykształcona i przedsiębiorcza. Ponadto do grupy tej weszły gminy uprzemysłowione oraz te o dominujących funkcjach turystycznych i uzdrowiskowych (Lutowiska, Cisna, Solina, Białowieża, Płaska). Można powiedzieć, że są to wiejskie obszary sukcesu gospodarczego, charakteryzujące się pomyślnym przebiegiem procesów społeczno-gospodarczych, które pobudzają lub wzmacniają rozwój ich struktur przestrzennych (Bański, 2008). Z badań Swianiewicza (2005) wynika, że względny sukces jest w dużej mierze efektem czynników miękkich, tj. obecności lidera, wizji, odpowiedniego poziomu optymizmu i aktywności zarówno liderów, jak i całej społeczności lokalnej.

\section{Poziom życia na obszarach wiejskich Polski Wschodniej}

Obserwując wartości syntetycznego wskaźnika poziomu życia (tab. 3), można stwierdzić, że na obszarach wiejskich Polski Wschodniej występuje znaczne zróżnicowanie przestrzenne poziomu życia ludności (ryc. 2). W 2012 r. w świetle przyjętych mierników syntetyczny wskaźnik poziomu życia wahał się tam w przedziale od -1,326 (gmina Wola Mysłowska, lubelskie) do 1,161 (gmina Krościenko Wyżne, podkarpackie), przy średniej wartości 0,003. Dla porównania: na obszarach wiejskich Polski wskaźnik ten był znacznie wyższy i wyniósł 0,044. Przyjmując za kryterium wartości powyższego wskaźnika, na obszarach wiejskich Polski Wschodniej wyróżniono pięć klas gmin: o bardzo niskim, niskim, średnim, wysokim oraz bardzo wysokim poziomie życia.

Tab. 3. Syntetyczny wskaźnik poziomu życia na obszarach wiejskich Polski Wschodniej w 2012 r.

\begin{tabular}{|l|r|r|c|c|}
\hline \multirow{2}{*}{\multicolumn{1}{|c|}{ Poziom życia }} & \multicolumn{2}{c|}{ Liczba } & \multicolumn{2}{c|}{ Struktura [\%] } \\
\cline { 2 - 5 } & gmin & \multicolumn{1}{c|}{ ludności } & gmin & ludności \\
\hline Bardzo niski (-0,244 i mniej) & 116 & 776430 & 18,2 & 18,6 \\
\hline Niski (-0,243-0,002) & 237 & 1473794 & 37,1 & 35,3 \\
\hline Średni (0,003-0,245) & 167 & 1035731 & 26,1 & 24,8 \\
\hline Wysoki (0,246-0,494) & 85 & 600779 & 13,3 & 14,4 \\
\hline Bardzo wysoki (0,495 i więcej) & 34 & 290641 & 5,3 & 6,9 \\
\hline Razem & 639 & 4177375 & 100,0 & 100,0 \\
\hline
\end{tabular}

Źródło: opracowanie własne na podstawie www.stat.gov.pl.

W gminach o bardzo niskim poziomie życia wskaźnik syntetyczny przyjął wartości poniżej -0,244. Było 116 (18,2\%) takich jednostek, mieszkało w nich 18,6\% ludności wiejskiej Polski Wschodniej. Najniższe wartości odnotowano w gminach: Wola Mysłowska (-1,326, lubelskie), Stąporków (-0,804, świętokrzyskie) oraz Opatów (-0,749, świętokrzyskie). Gminy z tej grupy leżą peryferyjnie w stosunku do największych ośrodków miejskich, jak również głównych szlaków komunikacyjnych. Jak wskazują badania, są to gminy słabo rozwinięte, o dużym odsetku bezrobotnych, małej liczbie ludności oraz niskim kapitale ludzkim (Kamińska, 2011). Jednostki te cechowały się najniższymi wartościami we wszystkich badanych dziedzinach określających 
poziom życia. Odznaczały się przede wszystkim wysokim odsetkiem osób bezrobotnych oraz korzystających z pomocy społecznej, niskim odsetkiem ludności korzystającej z instalacji wodociągowej, a także niewielkim odsetkiem mieszkań wyposażonych w łazienki.

Ryc. 2. Przestrzenne zróżnicowanie syntetycznego wskaźnika poziomu życia na obszarach wiejskich Polski Wschodniej

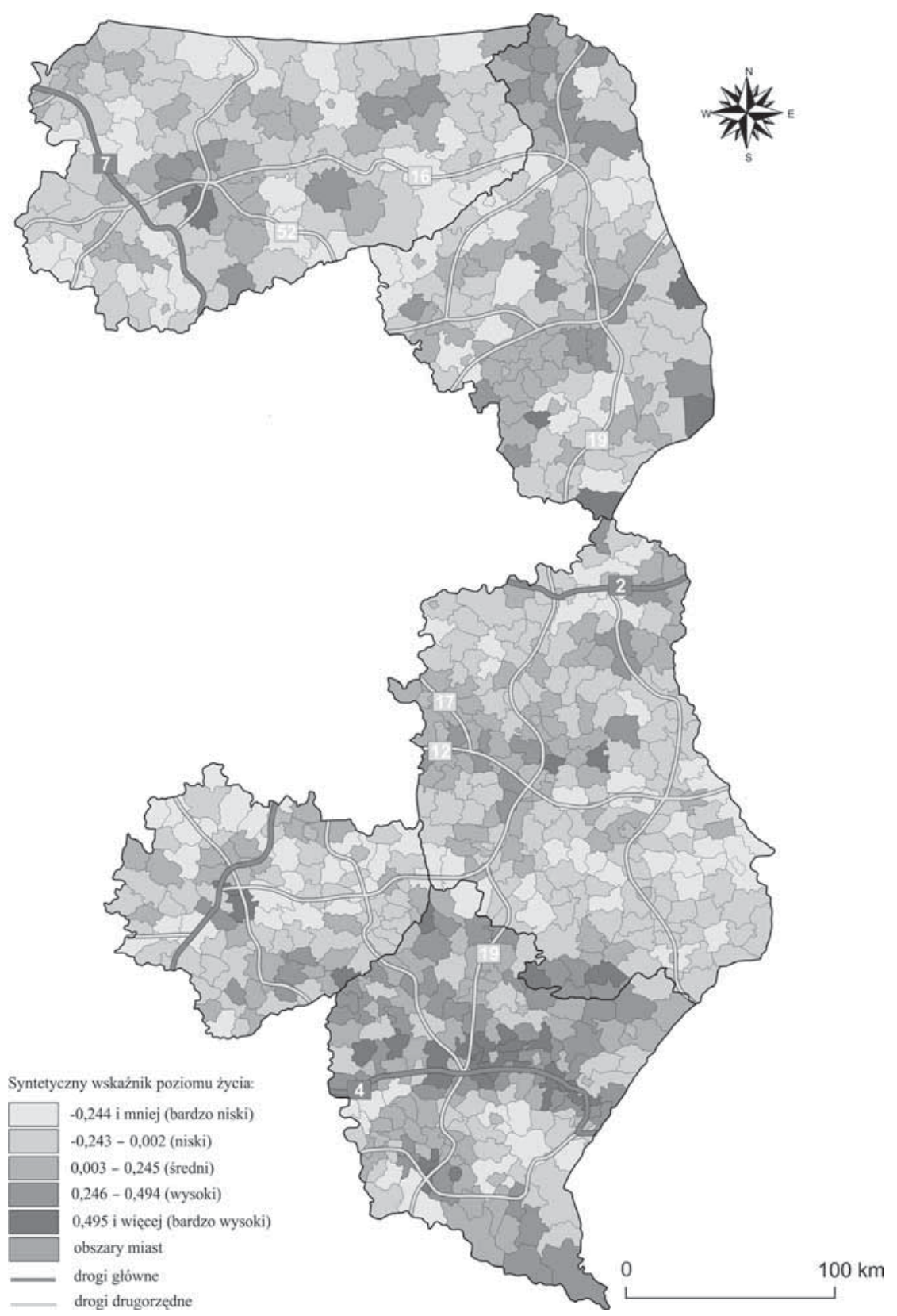

Źródło: opracowanie własne na podstawie www.stat.gov.pl. 
Najliczniejszą grupę stanowiły gminy o niskim poziomie życia, w których wskaźnik syntetyczny przyjął wartości w przedziale -0,243-0,002. Było to 237 jednostek $(37,1 \%)$, skupiających 35,3\% ludności wiejskiej Polski Wschodniej. Do grupy tej głównie należały gminy położone peryferyjnie w stosunku do dużych ośrodków miejskich, gdzie dostęp do usług wyższego rzędu jest znacznie ograniczony. Ponadto jednostki te to przeważnie tereny rolnicze, cechujące się dobrze rozwiniętymi, silnymi więziami obywatelskimi, co może wskazywać na wysoki poziom kapitału społecznego (Kamińska, 2011). Przy odpowiednim zaangażowaniu społeczności lokalnych jednostki te będą zmierzać w kierunku wielofunkcyjnego rozwoju, jednak obecnie charakteryzują się wysokim odsetkiem bezrobotnych, niskim współczynnikiem skolaryzacji oraz niewielkim odsetkiem ludności korzystającej z oczyszczalni.

Gminy o średnim poziomie życie, gdzie wskaźnik syntetyczny wahał się od 0,003 do 0,245, obejmowały 167 gmin (26,1\%), skupiających 24,8\% ludności wiejskiej Polski Wschodniej. Jednostki te położone były między gminami o wysokim i niskim poziomie życia, wokół największych miast regionu oraz w cieniu małych miast powiatowych. Sporą ich grupę stanowiły części wiejskie gmin miejsko-wiejskich oraz te znajdujące się przy głównych szlakach komunikacyjnych. W zależności od tendencji rozwojowych oraz zaangażowania społeczności lokalnych jednostki te w najbliższych latach mogą się stać obszarami o wysokim lub niskim poziomie życia ludności. Charakteryzują się one względnie wysokimi wydatkami budżetów jednostek samorządu terytorialnego na 1 mieszkańca, zaś pozostałe omawiane cechy oscylują w granicach średnich.

Gminy o wysokim poziomie życia, w których wskaźnik syntetyczny mieścił się w granicach 0,246-0,494, tworzyło 85 gmin (13,3\%), skupiających 14,4\% ludności wiejskiej Polski Wschodniej. Otaczają one gminy o bardzo wysokim poziomie życia - jednostki te pretendują do gmin rozwiniętych, przede wszystkim dzięki intensywnemu i towarowemu rolnictwu (Kulikowski, 2012) oraz dobrze rozwiniętych funkcjach pozarolniczych. Położone są wzdłuż głównych szlaków komunikacyjnych, wokół największych miast regionu (Rzeszów, Lublin, Białystok, Olsztyn) oraz w okolicy miast powiatowych (Krosno, Przemyśl, Stalowa Wola, Puławy, Suwałki, Augustów, Giżycko). W Przemyślu działają m.in. zakłady kosmetyczne Inglot, Zakłady Płyt Pilśniowych „Fibris” oraz wytwórnia farb i pomocy szkolnych „Pollena Astra”, a w Puławach znajdują się Zakłady Azotowe „Puławy” będące największym producentem nawozów sztucznych w Polsce. Ponadto jednostki te mają dobrze rozwinięte funkcje turystyczne: Augustów to znane uzdrowisko klimatyczne, zaś Giżycko nazywane jest stolicą żeglarstwa w Polsce. Dzięki położeniu w bliskiej odległości od ośrodka miejskiego średni czasu dojazdu do pracy w mieście zajmuje ok. 30-40 min. Jest to zgodne z tezą Czapiewskiego (2011), że wiejskie obszary sukcesu mają korzystną dostępność czasową do ośrodków miejskich. Obecnie jednostki te cechują się relatywnie niską stopą zgonów, niewielkim bezrobociem, dużym odsetkiem mieszkań wyposażonych w łazienki oraz wysokim odsetkiem ludności korzystającej z instalacji wodociągowej i oczyszczalni ścieków. Ich charakterystyczne położenie wokół gmin o bardzo wysokim poziomie życia pozwala przypuszczać, że w najbliższej przyszłości - przy sprzyjających warunkach społeczno-gospodarczych - mogą się one znaleźć właśnie w tej grupie gmin. Do grupy o bardzo wysokim poziomie życia, gdzie wskaźnik syntetyczny przyjął wartości powyżej 0,495, zaliczono 34 gminy (5,3\%), które skupiały 6,9\% ludności wiejskiej Polski Wschodniej. Najwyższe wartości odnotowano w gminach Krościenko Wyżne (1,161, podkarpackie), Puchaczów (1,117, lubelskie) oraz Gorzyce (0,986, podkarpackie). Były to głównie gminy leżące w strefach podmiejskich największych miast regionu, tj. Rzeszowa, Lublina, Olsztyna i Kielc, czyli na obszarach o dobrze wykształconych funkcjach usługowych i mieszkaniowych. Ponadto do grupy tej weszły gminy położone wzdłuż głównych szlaków 
komunikacyjnych, gminy uprzemysłowione oraz te o dominujących funkcjach turystycznych i uzdrowiskowych (Łańcut, Iwonicz-Zdrój, Białowieża). Obszary te charakteryzowały się także bardzo wysokimi wydatkami budżetów jednostek samorządu terytorialnego na 1 mieszkańca, niewielkim odsetkiem osób bezrobotnych, niskimi wartościami współczynnika zgonów oraz dobrym wyposażeniem mieszkań w infrastrukturę komunalną.

\section{Zależność między przedsiębiorczością a poziomem życia ludności na obszarach wiejskich Polski Wschodniej}

Przeprowadzona analiza wykazała, że brakuje silnej korelacji między przedsiębiorczością a poziomem życia ludności na obszarach wiejskich Polski Wschodniej. Współczynnik korelacji wyniósł 0,306. Zależność między poziomem przedsiębiorczości a poziomem życia potwierdziła się w 375 badanych jednostkach przestrzennych $(58,7 \%)$. Natomiast w świetle przyjętych mierników w pozostałych 264 gminach takiej zależności nie stwierdzono (tab. 4). Należy sobie zdawać sprawę z tego, że zarówno przedsiębiorczość, jak i poziom życia ludności są wypadkową wielu różnych czynników, które wykraczają poza mierniki przyjęte w niniejszej pracy.

Tab. 4. Typologia gmin ze względu na wysokość wskaźnika przedsiębiorczości i syntetycznego wskaźnika poziomu życia na obszarach wiejskich Polski Wschodniej

\begin{tabular}{|l|c|c|c|c|}
\hline \multirow{2}{*}{\multicolumn{1}{|c|}{ Typ gminy }} & \multicolumn{2}{c|}{ Liczba } & \multicolumn{2}{c|}{ Struktura [\%] } \\
\cline { 2 - 5 } & gmin & ludności & gmin & ludności \\
\hline Wysoki PŻ / wysoki PP & 147 & 1166884 & 23,0 & 27,9 \\
\hline Wysoki PŻ / niski PP & 139 & 990475 & 21,7 & 23,7 \\
\hline Niski PŻ / wysoki PP & 125 & 760267 & 19,6 & 18,2 \\
\hline Niski PŻ / niski PP & 228 & 1259749 & 35,7 & 30,2 \\
\hline Razem & 639 & 4177375 & 100,0 & 100,0 \\
\hline
\end{tabular}

Źródło: opracowanie własne na podstawie www.stat.gov.pl.

Ze względu na wysokość wskaźnika przedsiębiorczości i syntetycznego wskaźnika poziomu życia na obszarach wiejskich Polski Wschodniej wyróżniono cztery typy gmin (tab. 4, ryc. 3):

- o wysokim poziomie życia i wysokim wskaźniku przedsiębiorczości (gdzie uwzględniono obie wartości powyżej średniej dla regionu). W grupie tej znalazło się 147 (23\%) badanych gmin, skupiających 27,9 \% ludności wiejskiej Polski Wschodniej. Są to gminy bezpośrednio graniczące z największymi miastami regionu, gminy o funkcjach turystycznych i przemysłowych. Można powiedzieć, że są to wiejskie obszary sukcesu gospodarczego, charakteryzujące się pomyślnym przebiegiem procesów społeczno-gospodarczych, które pobudzają lub wzmacniają rozwój ich struktur przestrzennych (Bański, 2008). Ponadto w gminach tych prowadzona jest świadoma i konsekwentna polityka inwestycyjna w kapitał ludzki - badania Kamińskiej $(2010,2011)$ potwierdziły, że są to gminy o wysokich zasobach kapitału ludzkiego, na którego stan decydujący wpływ miały silnie rozwijające się funkcje przemysłowe oraz układy komunikacyjne wpływające na dostępność poszczególnych gmin do ośrodków miejskich;

- o wysokim poziomie życia i niskim wskaźniku przedsiębiorczości. Znalazło się tu 139 gmin (21,7\%), skupiających 23,7 \% ludności. Były to głównie jednostki o charakterze rolniczym, w których kładzie się nacisk na aktywizację ludności wiejskiej. Lokalna społeczność powinna uczynić wszystko, aby wykorzystać szansę i sprawić, by wysoki poziom życia stał się przyczynkiem do osiedlania się tam ludności młodej i dobrze wykształconej. Jak podają 
Kłodziński i Dzun (2003), różnice w wykorzystaniu instrumentów wspierających rozwój lokalny nie wynikają z poziomu zasobów materialnych, którymi dysponują poszczególne gminy, ale z zaangażowania ludzi, gdyż to oni są główną determinantą sukcesu - ich przedsiębiorczość oraz zdolność do samoorganizowania i współdziałania;

Ryc. 3. Zależność między przedsiębiorczością a poziomem życia ludności na obszarach wiejskich Polski Wschodniej

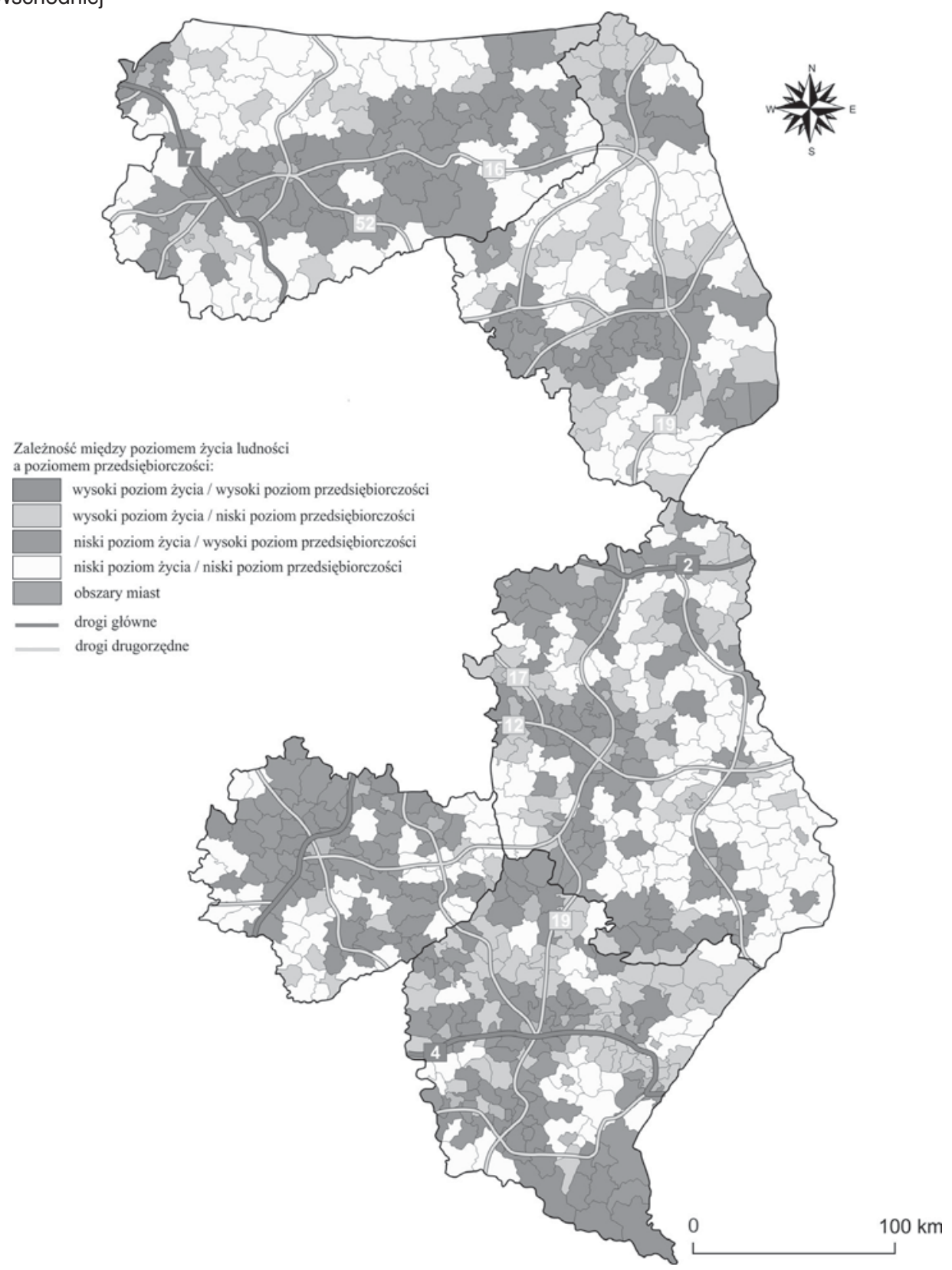

Źródło: opracowanie własne na podstawie www.stat.gov.pl. 
- o niskim poziomie życia i wysokim wskaźniku przedsiębiorczości. Grupę tę stanowiło125 gmin (19,6\%), na których obszarze mieszkało 18,2 \% ludności wiejskiej Polski Wschodniej. Rozmieszczone są wyspowo i otaczają gminy z poprzedniej grupy, a dużą ich część stanowią jednostki o bardzo dobrze rozwiniętych funkcjach turystycznych. Ponadto charakteryzują się towarowym rolnictwem, wysoko rozwiniętymi funkcjami pozarolniczymi, a także średnimi zasobami kapitału ludzkiego (Kamińska, 2011). W zależności od zaangażowania społeczności lokalnych jednostki te w najbliższych latach mogą się stać obszarami o wysokim poziomie życia ludności;

- o niskim poziomie życia i niskim wskaźniku przedsiębiorczości, gdzie obydwie wartości były poniżej średniej dla badanego obszaru. Niestety była to najliczniejsza grupa 228 gmin $(35,7 \%)$, skupiających 30,2\% ludności wiejskiej regionu. Były to gminy słabo rozwinięte, o dużym odsetku osób bezrobotnych, małej liczbie ludności - położone peryferyjnie zarówno w stosunku do dużych ośrodków miejskich, jak i dróg głównych. Ponadto do grupy tej zaliczono wiejskie obszary depopulacyjne o niekorzystnych strukturach demograficznych (Baran, Kopacz-Wyrwał, 2014). Do najważniejszych z nich należy zaliczyć zwichniętą równowagę płci, starzenie się społeczeństwa, odpływ ludzi młodych i przedsiębiorczych, a także spadek liczby urodzeń. Dalsze pogłębianie się procesów depopulacji na tym obszarze prowadzić będzie do narastających, negatywnych zjawisk społecznych (patologie), ubożenia społeczeństwa, a w konsekwencji do dalszego spadku poziomu życia ludności.

\section{Zakończenie}

Przeprowadzona analiza wykazała, że na obszarach wiejskich Polski Wschodniej występuje znaczne zróżnicowanie przestrzenne poziomu przedsiębiorczości i poziomu życia ludności. Wynika to z ogólnego rozwoju społeczno-gospodarczego tych obszarów, a wpływ na taką sytuację miał głównie poziom uprzemysłowienia, stopień urbanizacji obszarów wiejskich oraz funkcjonowanie aglomeracji miejskich (Zeliaś, 2004; Kamińska, 2010). Ponadto badania wykazały, że na obszarach wiejskich Polski Wschodniej brakuje silnej korelacji między przedsiębiorczością a poziomem życia ludności. Współczynnik korelacji wyniósł 0,306. Zależność między poziomem przedsiębiorczości a poziomem życia potwierdziła się w 375 badanych jednostkach przestrzennych, natomiast w świetle przyjętych mierników w pozostałych 264 gminach takiej zależności nie stwierdzono. Należy jednak podkreślić, że zarówno przedsiębiorczość, jak i poziom życia ludności są wypadkową wielu różnych czynników, które wykraczają poza mierniki przyjęte $\mathrm{w}$ niniejszej pracy. W związku $\mathrm{z}$ tym $\mathrm{w}$ gminach tych istnieje potrzeba przeprowadzenia dalszych, szczegółowych badań, które być może pozwolą wyjaśnić brak zależności między przedsiębiorczością a poziomem życia.

W świetle przyjętych mierników najwyższe wartości syntetycznego wskaźnika poziomu życia odnotowano na wiejskich obszarach progresji, położonych w sąsiedztwie dużych ośrodków miejskich (Kielce, Rzeszów, Krosno, Stalowa Wola, Lublin, Puławy, Białystok, Suwałki, Giżycko, Olsztyn, Elbląg), wzdłuż głównych szlaków komunikacyjnych, na obszarach o dobrze rozwiniętych funkcjach usługowych, przemysłowych i mieszkaniowych. W wyniku nagromadzenia różnych zjawisk społecznych (np. napływ migracyjny, aktywność mieszkańców, wysoki poziom wykształcenia) i ekonomicznych (napływ inwestycji, dobre wyposażenie w infrastrukturę, sąsiedztwo dużego rynku zbytu i rynku pracy) sprzyjających rozwojowi gospodarczemu są one skazane na sukces (Bański, 2008). Ponadto część tego typu gmin ma bardzo dobrze rozwinięte funkcje turystyczne - atrakcyjna lokalizacja pod kątem turystyki odgrywa bardzo ważną rolę w generowaniu sukcesu gminy. Położenie na obszarach górskich i podgórskich (województwo podkarpackie) oraz na obszarach pojezierzy jest praktycznie jedynym atutem tych jednostek. 
W związku z tym działania mieszkańców i samorządowych władz lokalnych na tych obszarach skierowane są na wzbogacenie oferty turystycznej oraz marketing i promocję. Należy dodać, że wiejskie obszary progresji charakteryzują się na ogół stałym trendem wzrostu gospodarczego, wynikającym z pomyślnej realizacji różnych przedsięwzięć społeczno-gospodarczych (Bański, 2008). Efektem tego jest wielofunkcyjność gminy, dobrze rozwinięta infrastruktura techniczna, wysoki poziom przedsiębiorczości i aktywności społecznej mieszkańców oraz wysoka efektywność podmiotów gospodarczych (Heffner, 2007).

Najniższe wartości wskaźnika przedsiębiorczości i syntetycznego wskaźnika poziomu życia odnotowano na obszarach peryferyjnych. Pokrywają się one z rejonami monofunkcyjnymi rolniczo, cechującymi się niskim poziomem gospodarki rolnej, problemami demograficznymi (depopulacja, emigracja), społecznymi (starość, feminizacja) i niskim poziomem inwestycji na wsi (Stanny, 2009). Należy także podkreślić, że wśród tych jednostek dominowały takie obszary depopulacyjne, z których odpływają głównie ludzie młodzi, w wieku produkcyjnym. Taka sytuacja prowadzi do spadku liczby zawieranych małżeństw oraz stopy urodzeń. Ponadto, według Bańskiego (2008), im dalej w kierunku peryferii, tym znacznie trudniej o sukces gospodarczy niezwiązany z działalnością rolniczą. Twórcą sukcesu gospodarczego na obszarach peryferyjnych powinien być przede wszystkim rolnik-przedsiębiorca, który zdecyduje się na ryzyko podjęcia nowych inwestycji. Niska aktywność i brak przedsiębiorczości hamują szanse wyjścia z ubóstwa, a niski poziom kapitału ludzkiego i społecznego jeszcze tę biedę może pogłębić, gdyż jest on uwarunkowany skłonnością jednostek do działania w zbiorowości, zdolnością do generowania nowych powiązań, kontaktów i sieci (Będzik, 2008).

Ciekawym przypadkiem są gminy o wysokim poziomie życia, ale niskim wskaźniku przedsiębiorczości. Są to gminy położone peryferyjnie, wzdłuż granic wojewódzkich, mające charakter rolniczy, w których prowadzone są intensywne działania aktywizujące ludność wiejską. Dzięki temu możliwe jest na tych obszarach pobudzanie lokalnych inicjatyw, a tym samym budowanie kapitału społecznego na wsi (Heffner, 2012). Jednak mimo wysokiego poziomu życia obszary wiejskie położone z dala od krajowych lub regionalnych centrów ekonomicznych są mniej atrakcyjne dla potencjalnych inwestorów, mają także mniejsze szanse rozwoju zróżnicowanych funkcji gospodarczych.

Badania wykazały ponadto, że istnieją gminy cechujące się niskim poziomem życia, ale wysokim wskaźnikiem przedsiębiorczości. Gminy te mają dobrze rozwiniętą funkcję turystyczną. Taka sytuacja może wynikać z atrakcyjnego - pod względem krajobrazowym i przyrodniczym - położenia tych obszarów. Są to malownicze tereny górskie, podgórskie oraz pojezierza, w których prężnie rozwija się działalność turystyczna i uzdrowiskowa. Obecnie ludność coraz bardziej ceni sobie walory krajobrazowe i estetykę przyrodniczą miejsca, w którym mieszka lub wypoczywa. Ponadto są to gminy położone wzdłuż głównych arterii komunikacyjnych, co umożliwia mieszkańcom łatwy dostęp do pobliskich ośrodków miejskich.

Pomimo intensywnie prowadzonej polityki spójności na obszarach wiejskich Polski Wschodniej ciągle wyraźnie zaznacza się dychotomia miasto - wieś oraz gminy podmiejskie - gminy peryferyjne. Lokalne władze samorządowe, jak również administracja centralna, powinny podjąć wszelkie możliwe działania zmierzające do wyrównania warunków ekonomicznych i społecznych we wszystkich regionach Unii Europejskiej. Tylko intensywne prace mogą w niedalekiej przyszłości stworzyć warunki do wzrostu poziomu społeczno-gospodarczego obszarów wiejskich Polski Wschodniej, skutecznie przeciwdziałać degradacji wsi i wspomagać proces modernizacji rolnictwa. Brak działań, zwłaszcza ze strony władz lokalnych, będzie prowadzić do pogłębiających się procesów bezrobocia i dalszego spadku poziomu życia na tych obszarach. 


\section{Literatura}

References

Bański, J. (2002). Obszary problemowe Małopolski. W: A. Jelonek, Z. Górka (red.), Geograficzne uwarunkowania rozwoju Małopolski. Kraków: IGiGP UJ, 299-305.

Bański, J., Stola, W. (2002). Przemiany struktury przestrzennej i funkcjonalnej obszarów wiejskich w Polsce. Studia Obszarów Wiejskich, t. III. Warszawa: IGiPZ PAN.

Bański, J. (2008). Wiejskie obszary sukcesu gospodarczego. Warszawa: IGiPZ PAN.

Baran, E., Kopacz-Wyrwał, I. (2014). Poziom życia a procesy depopulacji na obszarach wiejskich południowo-wschodniej Polski. W: W. Kamińska, K. Heffner (red.), Obszary wiejskie: wielofunkcyjność, migracje, nowe wizje rozwoju. Studia KPZK PAN, t. CXXXIII. Warszawa: KPZK PAN, 168-194.

Berbeka, J. (2006). Poziom życia ludności a wzrost gospodarczy w krajach Unii Europejskiej. Kraków: AE.

Będzik, B. (2008). Kapitał społeczny jako ważny czynnik rozwoju obszarów wiejskich. Rozwój zasobów kapitału ludzkiego obszarów wiejskich. Studia i Prace Wydziału Nauk Ekonomicznych i Zarządzania Uniwersytetu Szczecińskiego, 8, 40-47.

Bywalec, C. (1986). Wzrost gospodarczy a przemiany poziomu życia społeczeństwa polskiego w latach 1945-1980. Zeszyty Naukowe AE, 70, 11-17.

Chojnicki, Z., Czyż, T. (red.). (1991). Zróżnicowanie przestrzenne poziomu i warunków życia ludności. Warszawa: KPZK PAN.

Czapiewski, K. (2011). Location Matters - analiza zależności pomiędzy dostępnością przestrzenną a sukcesem społeczno-gospodarczym obszarów wiejskich Mazowsza. W: M. Wesołowska (red.), Wiejskie obszary peryferyjne - uwarunkowania i czynniki aktywizacji, Studia Obszarów Wiejskich, t. XXVI. Warszawa: IGiPZ PTG, 57-73.

Gaweł, A. (2007). Ekonomiczne determinanty przedsiębiorczości. Poznań: Wyd. Akademii Ekonomicznej w Poznaniu.

Heffner, K. (2007). Rozwój społeczno-gospodarczy obszarów wiejskich. Definicje - Uwarunkowania Zależności - Czynniki - Skutki. Badania zróżnicowania rozwoju obszarów wiejskich. W: A. Rosner (red.), Zróżnicowanie poziomu rozwoju społeczno-gospodarczego obszarów wiejskich, a zróżnicowanie dynamiki przemian. Warszawa: IRWiR PAN, 11-26.

Heffner, K. (2012). Wiejskie rynki pracy w Polsce - kurczące się zasoby czy niewyczerpane rezerwy? Wiejskie rynki pracy - zasoby, aktywizacja, nowe struktury. Studia KPZK PAN, t. CXLV, 8-51.

Hydzik, P. (2012). Zastosowanie metod taksonomicznych do oceny poziomu rozwoju społeczno-ekonomicznego powiatów województwa podkarpackiego. Zeszyty Naukowe Politechniki Rzeszowskiej, Ekonomia i Nauki Humanistyczne, 9, 17-33.

Jaremczuk, K. (2003). Uwarunkowania rozwoju przedsiębiorczości-szanse i zagrożenia. Tarnobrzeg: Wydawnictwo PWSZ.

Kaliszczak, L. (2002). Źródła sukcesu małych i średnich przedsiębiorstw w warunkach zmiennego otoczenia. W: J. Targalski (red.), Uwarunkowania sukcesu przedsiębiorstwa. Kraków: Wydawnictwo Akademii Ekonomicznej w Krakowie, 5-18.

Kamińska, W. (2010). Urbanizacja obszarów wiejskich województwa świętokrzyskiego. Kielce: IG UJK.

Kamińska, W. (2011). Kapitał ludzki i społeczny na obszarach wiejskich w Polsce. Przykład województwa świętokrzyskiego. Kielce: IG UJK.

Kłodziński, M., Dzun, W. (red.). (2003). Aktywizacja wiejskich obszarów problemowych. Szczecin, Warszawa: IRWiR PAN, KROWiOGŻ AR.

Kopacz, I. (2011). Poziom życia a procesy depopulacji na obszarach wiejskich woj. świętokrzyskiego. Obszary wiejskie: wielofunkcyjność, migracje, nowe wizje rozwoju. Studia KPZK PAN, t. CXXXIII, 214-227.

Kudełko, J. (2013). Uwarunkowania i kierunki rozwoju województw Polski Wschodniej jako regionów słabo rozwiniętych. Warszawa: KPZK PAN.

Kulikowski, R. (2012). Produktywność i towarowość rolnictwa w Polsce. Barometr Regionalny. Analizy. Prognozy, 4, 17-29.

Leszczewska, K. (2012). Zasoby kapitału ludzkiego a rozwój przedsiębiorczości w Polsce. Nierówności społeczne a wzrost gospodarczy. Modernizacja dla spójności społeczno-ekonomicznej w czasach kryzysu, 24, Rzeszów: Uniwersytet Rzeszowski, 412-421. 
Liszewski, S. (1995). Zróżnicowanie przestrzenne poziomu i jakości warunków życia ludności w aglomeracjach miejskich (Program badań, pierwsze wyniki). Acta Universitatis Lodziensis, Folia Geographica, 20, 7-17.

Luszniewicz, A. (1972). Statystyka poziomu życia ludności. Warszawa: PWE.

Luszniewicz, A. (1983). Statystyka społeczna: podstawowe problemy i metody. Warszawa: PWE.

Makieła, Z. (2008). Przedsiębiorczość regionalna. Warszawa: Difin.

Miszczuk, A., Wesołowska, M. (2012). Uwarunkowania demograficzne wiejskich rynków pracy Polski Wschodniej - ujęcie typologiczne. Wiejskie rynki pracy-zasoby, aktywizacja, nowe struktury. Studia KPZK PAN, t. CXLV, 209-228.

Piasny, J. (1993). Poziom i jakość życia ludności oraz źródła i mierniki ich określania. Ruch Ekonomiczny, Prawniczy i Socjologiczny, 2, 73-92.

Rosner, A. (2007). Zróżnicowanie poziomu rozwoju społeczno-gospodarczego obszarów wiejskich a zróżnicowanie dynamiki przemian. Warszawa: IRWiR PAN.

Schumpeter, J.A. (1960). Teoria rozwoju gospodarczego. Warszawa: PWN.

Słaby, T. (2007). Poziom życia i jakość życia. W: T. Panek (red.), Statystyka społeczna. Warszawa: PWE, 38-51.

Stanny, M. (2009). Zróżnicowanie poziomu rozwoju obszarów wiejskich w Polsce a problem realizacji polityki spójności. Wieś i Rolnictwo, 4, 246-257.

Swianiewicz, P. (2005). Strategiczna analiza stanu spójności ekonomicznej i społecznej przeprowadzona na poziomie obszarów NUTS4 i NUTS. Pozyskano z: https://www.mir.gov.pl/rozwoj_regionalny/ poziom_regionalny/strategia_rozwoju_polski_wschodniej_do_2020/dokumenty/Documents/75a31326e6034163afc4c99b4cc11d9dSwianiewicz.pdf

Szymla, Z. (2004). Przestrzenne zróżnicowanie warunków życia ludności w województwie małopolskim. Zeszyty Naukowe Akademii Ekonomicznej w Krakowie, 645, 5-20.

Sztucki, T. (1998). Encyklopedia marketingu. Warszawa: Wydawnictwo Placet.

Targalski, J. (1999). Przedsiębiorczość i rozwój firmy. Kraków: Wydawnictwo Akademii Ekonomicznej w Krakowie.

Wach, K. (2013). Edukacja na rzecz przedsiębiorczości wobec współczesnych wyzwań cywilizacyjno-gospodarczych. Przedsiębiorczość - Edukacja, 9, 247-248.

Zagórski, K., Gorzelak, G., Jałowiecki, B. (2009). Zróżnicowania warunków życia. Polskie rodziny i spoteczności lokalne. Warszawa: Wyd. Naukowe SCHOLAR.

Zeliaś, A. (2000). Taksonomiczna analiza przestrzennego zróżnicowania poziomu życia w Polsce w ujęciu dynamicznym. Kraków: AE.

Zeliaś, A. (2004). Poziom życia w Polsce i krajach Unii Europejskiej. Warszawa: PWE.

Iwona Kopacz-Wyrwal, mgr, od 2008 r. zatrudniona w Zakładzie Geografii Społeczno-Ekonomicznej Instytutu Geografii Uniwersytetu Jana Kochanowskiego w Kielcach na stanowisku asystenta. Przewód doktorski otworzyła w maju 2012 r. Zainteresowania badawcze autorki skupiają się wokół tematów obszary wiejskie (warunki życia, jakość życia, poziom życia, przedsiębiorczość, strefa podmiejska, obszary peryferyjne, turystyka wiejska) oraz małe miasta.

Iwona Kopacz-Wyrwal, since 2008 employed in Zakład Geografii Społeczno-Ekonomicznej Instytutu Geografii Uniwersytetu Jana Kochanowskiego on assistant position. Doctoral dissertation has been opened in May 2012. Research works: rural areas (living conditions, quality of life, standard of living, entrepreneurship, suburbs, peripheral areas, rural tourism) and small towns.

Adres/Address: $\quad$ Uniwersytet Jana Kochanowskiego

Instytut Geografii

ul. Świętokrzyska 15

25-406 Kielce, Polska

e-mail: iwona.k9@wp.pl 